\title{
Squamous Cell Carcinoma in a Thyroglossal Duct Cyst: A Caribbean Case Report
}

\author{
Forde $^{1}, \mathrm{~N}_{\text {Williams }}^{2}$
}

Introduction: Thyroglossal duct cyst (TGDC) has a prevalence of approximately $7 \%$ in the adult population (1). Malignant transformation in TGDC is rare and accounts for about $1 \%$ of all these cyts of which the majority are papillary carcinomas (2). Squamous cell carcinoma is even rarer with only a few cases reported in the literature (2). There is no published literature in the West Indies regarding the management of squamous cell carcinoma in a TGDC. This report highlights such a case and aims to review the current diagnosis and treatment of this disease entity.

Keywords: Parathyroid cancer, squamous cell carcinoma, thyroglossal duct cyts carcinoma

\section{El Carcinoma de Células Escamosas en un Quiste del Conducto Tirogloso: Un Reporte de Caso del Caribe}

\author{
R Forde $^{1}, \mathrm{~N}_{\text {Williams }}^{2}$
}

\begin{abstract}
Introducción: El quiste del conducto tirogloso (QCTG) tiene una prevalencia de aproximadamente $7 \%$ en la población adulta. La transformación maligna en QCTG es rara y representa cerca de $1 \%$ de todos estos quistes, la mayor parte de los cuales son carcinomas papilares. El carcinoma de célula de escamosas es incluso más raro, con solamente algunos casos reportados en la literatura. No hay literatura publicada en West Indies en relación con el manejo del carcinoma de célula escamosas en un quiste del conducto tirogloso. Este reporte destaca tal caso y tiene por objeto examinar el diagnóstico y tratamientos actuales de esta entidad patológica.
\end{abstract}

Palabras clave: Cáncer de paratiroides, carcinoma de células escamosas, carcinoma del quiste del conducto tirogloso

West Indian Med J 2017; 66 (6): 729

\section{CASE REPORT}

A 48-year-old hypertensive woman was referred to an outpatient Ears, Nose and Throat Clinic with a sixmonth history of an upper midline neck swelling which was increasing in size. It was associated with intermittent pain. Physical examination revealed a $4 \mathrm{~cm}$ by 3 $\mathrm{cm}$ firm, non-tender mass which moved on swallowing and with protrusion of the tongue. Laryngoscopy was normal. There were no palpable lymph nodes of the

From: ${ }^{1}$ Department of Surgery, Radiology, Anaesthesia and Intensive Care, Ears, Nose and Throat Division and ${ }^{2}$ Department of Pathology, The University of the West Indies, Kingston 7, Jamaica, West Indies. neck. Ultrasound revealed a 3.2 by 1.7 by $1.4 \mathrm{~cm}$ cystic midline lesion without any enlarged cervical lymph nodes and a $16 \mathrm{~mm}$ isoechoic thyroid nodule. Ultrasound guided fine needle aspiration cytology (FNAC) of this nodule revealed benign cells. Thyroid function tests were normal. Based on these findings, the patient was assessed as having a TGDC and had opted for observation. During observation, the patient was advised to remove the cyst. Three years later, she re-presented with 
a history of this long-standing midline mass which had recently grown rapidly and was now associated with constant pain. Physical examination revealed a $8 \mathrm{~cm}$ by $9 \mathrm{~cm}$ tender and immobile mass (Fig.1).

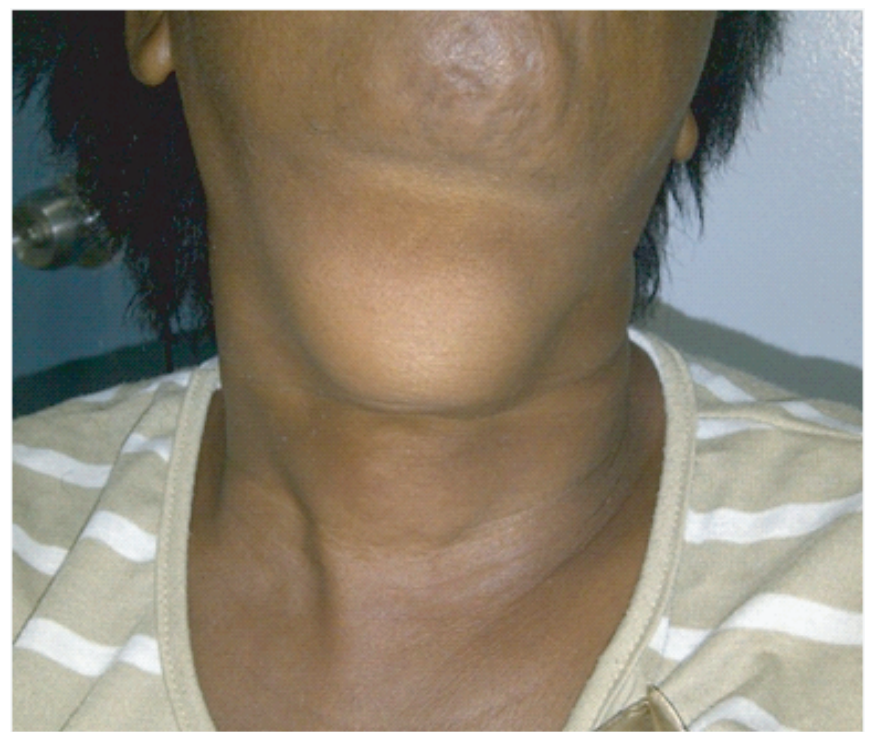

Fig 1: Anterior view of the neck of the patient showing a large midline neck swelling.

Ultrasound examination demonstrated a larger mass compared with the previous ultrasound and which now comprised of more solid components with a few cystic areas present. The isoechoic cyst in the left lobe now measured $18 \mathrm{~mm}$ and there was no cervical adenopathy. A surgical removal of the mass was decided and a wide Sistrunk's procedure was performed (Fig. 2).

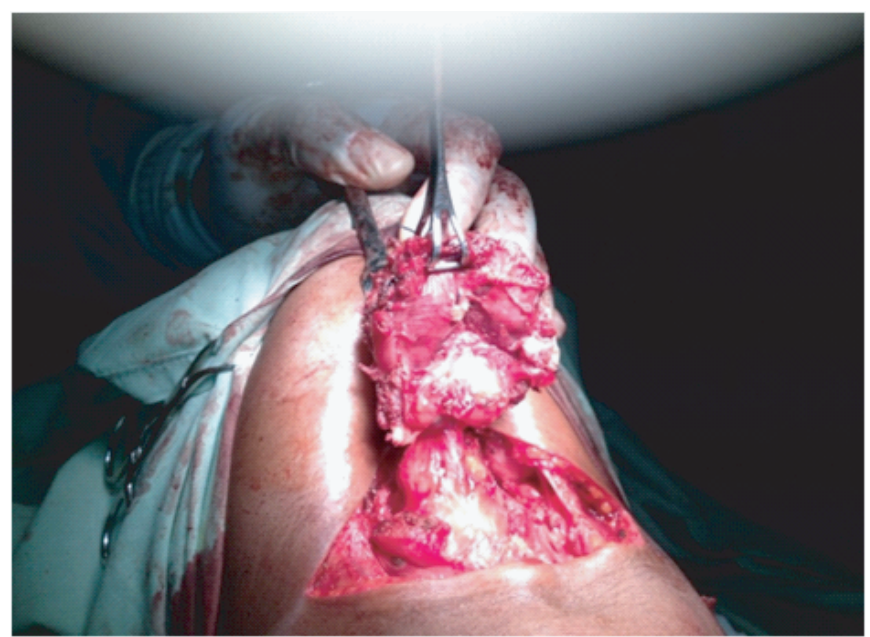

Fig 2: Right anterior lateral view of the neck of a patient undergoing a wide local excision of the thyroglossal cyst mass. The thyroglossal cyts mass including strap muscles and body of hyoid bone is being retracted superiorly.

At surgery a $6 \mathrm{~cm}$ by $4 \mathrm{~cm}$ mass was excised including the body of the hyoid bone. In addition, the strap muscles involved were removed. The overlying skin was not involved. The patient had an uneventful postoperative period and was discharged two days after admission. The histological evaluation revealed a moderately differentiated squamous cell carcinoma arising in an $0.5 \mathrm{~cm}$ epithelial cyst with infiltration into the attached strap muscle (Fig. 3).

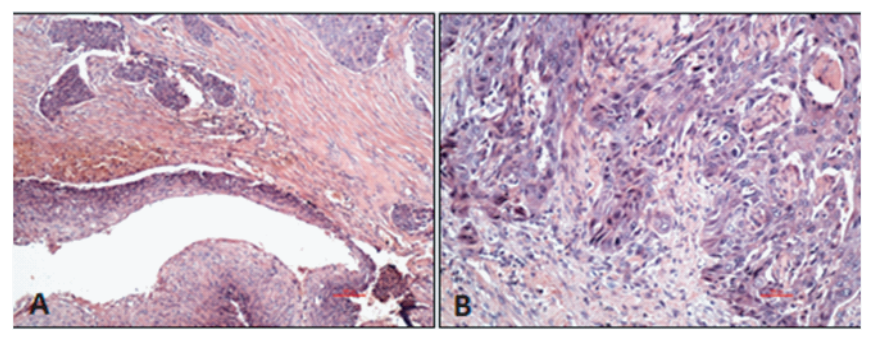

Fig. 3: (A) Low power image showing squamous epithelial lining of the cyst wall with tumour infiltration of the subjacent stroma. (B) High power image showing the histological detail of the squamous cell carcinoma with minimal keratinization and irregular infiltration of the stroma.

There were no lymphoid or thyroid follicles present in the wall. Subsequent staging 64 slice multi-detector computed tomography (CT) scan of the neck, chest, abdomen and pelvis showed partial resection of the hyoid bone and no residual mass or cervical adenopathy. Postoperative radiotherapy to the neck was administered. On follow-up two years after, there was no evidence of loco-regional recurrence.

\section{DISCUSSION}

Normally, the thyroid gland originates from the floor of the primitive pharynx in the three to four-week-old embryo (3). It then descends inferiorly from the base of the tongue region and passes anterior to the hyoid bone to lie anterior to the cervical trachea as the thyroid gland. The tract that connects this thyroid gland to the tongue superiorly will then obliterate at weeks seven to eight of gestation (3).

Failure of involution will lead to the formation of a TGDC or thyroglossal duct tract [TGDT] (3). The pyramidal lobe of the thyroid gland which is present in up to $50 \%$ of persons is the persistent inferior extent of the TGDT (3). The thyroglossal duct cyst is the most common cause of a congenital neck mass (4). A thyroglossal remnant can be a cyst, a tract or duct, or an ectopic thyroid within a cyst or within a duct (5). A tumour can arise from any one of these remnants. Benign TGDC comprise $75 \%$ of midline neck tumours in children and are found in 7\% of adults (6). Incidental thyroglossal duct cyst carcinoma (TDCa) is rare arising in $1 \%$ of TGDC but is more likely to occur in adults 
than children (4). Our case was the first case ever seen in the Ear, Nose and Throat Department at the University Hospital of the West Indies.

The number of reported cases in the literature is 15 (2). We were able to find and review seven case reports and so most of our deductions regarding diagnosis and treatment are based on available reports $(2,7-12)$. The average age of presentation is 65 years with a range of 55 to 78 years $(2,7,8,10,12)$. Our patient was 51 years at presentation. This is an older age group of presentation when compared to thyroid papillary cancer in a TGDC where the average age is 35 years (1). One may postulate that the predisposing factors that give rise to squamous cell carcinoma need a longer time to cause tumorigenesis, hence the presentation in an older population. There is no gender bias in the distribution of this tumour (7).

Papillary adenocarcinomas account for 75 to $85 \%$ of TDCa and mixed papillary/follicular is the next most common accounting for 7\% (5). Squamous cell carcinoma will account for approximately $5 \%$ and has the worst prognosis (5). The various types of carcinomas arising in the TGDT is explained by the various histological findings seen. The TGDT lining is usually composed of squamous epithelium and/or respiratory epithelium (3). Granulation tissue and also inflammatory cells can also be seen in the cases where there are recurrent infections and in some rare cases, salivary tissue and mucous glands have been described (3). Accessory thyroid tissue can occur anywhere along the extent of the TGDT and in excised TGDTs, of $62 \%$ were found to have a remnant of thyroid tissue (3). This explains why most of the malignancies are of thyroid origin. Therefore, Squamous cell carcinoma may be seen arising from the squamous epithelium of the TGDT. Squamous cell epithelium may also be seen as cell nests in the normal thyroid or it may be due to squamous metaplasia of thyroid follicular cells in goitres or thyroiditis (13). Squamous cell carcinoma of the thyroid gland may be arising from accessory thyroid tissue along the TGDT or may be arising from metastases to the thyroglossal remnant (6). In our case, there was absent thyroid tissue so it is more likely that the carcinoma arose de novo from the squamous epithelium of the TGDT rather than from thyroid tissue.

In terms of history, most patients in the literature gave a history of a recent rapid increase in size $(2,7)$ and one patient in the literature review gave a history of recurrent drainage and suppuration (12). The most common finding on examination was an immobile midline mass
$(2,8)$. One patient was found on examination to have a mobile mass which was excised and later found to contain an incidental TGDC squamous cell carcinoma (7).

Mobini et al have outlined four criteria which they considered necessary to accept that a squamous cell carcinoma had arose primarily in a TGDC or remnant (7). The four criteria are: 1: The presence of a thyroglossal duct or cysts, based on its midline or near midline position, its lining epithelium, and the presence of adjacent, ectopic, normal thyroid follicles, 2: Squamous cell carcinoma arising directly from the cysts wall, 3 : Transition between the epithelium of the duct or the cyts and the tumour mass, 4: Exclusion of other primary sites including the larynx (7). Our case had fulfilled all four criteria and so a diagnosis of primary TGDC squamous cell carcinoma was made.

The diagnostic accuracy of FNAC is low especially in the presence of cystic lesions and small mural tumours (6). However, the work-up should include ultrasound, FNAC and CT scans if there is an index of suspicion of squamous cell carcinoma (9). In our literature review, all patients who presented with clinical features of a recent rapid increase in size and an immobile mass were deemed suspicious for TDCa and underwent FNAC which revealed typical or atypical keratinised epidermoid cells which were suspicious for malignancy (2, 8). Our patient presented with the typical history of rapid increase in size and was found to have an immobile mass on palpation and so should have undergone a FNAC which if positive would have allowed better preoperative planning in terms of counselling of the patient regarding possible extent of surgery, surgical time and possible need for frozen section analysis.

The recommended treatment is wide local resection with frozen section control of margins (9). For localized lesions (incidental TDCa) the Sistrunk operation is adequate. But if at surgery a carcinoma is suspected based on pre-operative or intra-operative findings, then a wider resection should be performed which may include strap muscles (9). Thyroidectomy is not warranted because of the rarity of squamous cell carcinoma arising from the thyroid gland (3). Neck dissection is performed where there is evidence of metastatic cervical adenopathy and there is no role for prophylactic neck dissection (9). Postoperative radiotherapy to the neck is reserved for large lesions, positive surgical margins or where there is extensive nodal disease (9). Our patient had a wide local resection including the involved strap muscles and received postoperative radiotherapy. 


\section{CONCLUSION}

There are gaping holes in the clinical knowledge of this disease entity because, with the exception of a few case reports, there are no comparative studies on the diagnosis or treatment of these lesions and hence, there is no study of long-term follow-up. Carcinoma should be suspected in any patient presenting with a cyst with a history of a rapid increase in size and examination findings of an immobile mass. Suspicious clinical findings need to be further investigated with an ultrasound guided FNAC. The treatment should be a localized surgical excision in all adult patients and a wider resection where there is extension to surrounding structures followed by adjuvant radiation therapy.

\section{REFERENCES}

1. Manipadam JM, Manipadam MT, Thomas EM, Michael RC, Ramakant P, Abraham DT, et al. Thyroglossal duct carcinoma: a case series and approach to management. Agarwal A, editor. World J Endocr Surg [Internet]. 2011; 3: 59-63.

2. Iakovou I, Konstantinidis I, Doumas A, Nikolaidis V, Karatzas N, Efstratiou I. Squamous cell carcinoma in a thyroglossal duct cyst and 99mTc-MIBI findings. Hell J Nucl Med [Internet]. [cited 2014 Oct 15]; 14: $62-4$.

3. Woods RH, Saunders JR, Pearlman S, Hirata RM, Jaques DA. Anaplastic carcinoma arising in a thyroglossal duct tract. Otolaryngol Head Neck Surg 1993; 109: 945-9.
4. Ewing CA, Kornblut A, Greeley C, Manz H. Presentations of thyroglossal duct cysts in adults. Eur Arch Oto-Rhino-Laryngology [Internet]. 1999; Mar 26 [cited 2014; 21]; 256: 136-8.

5. Kennedy T, Whitaker M, Wadih G. Thyroglossal duct carcinoma: a rational approach to management. Laryngoscope [Internet]. 1998

6. Mazzaferri EL. Thyroid cancer in thyroglossal duct remnants: a diagnostic and therapeutic dilemma. Thyroid [Internet]. Mary Ann Liebert, Inc; 2004 May 9 [cited 2014 Sep 21]; 14: 335-6.

7. Colloby PS, Sinha M, Holl-Allen RTJ, Crocker J. Squamous cell carcinoma in a thyroglossal cyst remnant: a case report and review of the literature. World J Surg [Internet]. 1989 Jan [cited 2014 Sep 21]; 13: $137-9$.

8. Hama Y, Sugenoya A, Kobayashi S, Itoh N, Amano J. Squamous cell carcinoma arising from thyroglossal duct remnants: Report of a case and results of immunohistochemical studies. Surg Today [Internet]. 1997 Nov [cited 2014 Sep 21]; 27: 1077-81.

9. Hanna E. Squamous cell carcinoma in a thyroglossal duct cyst (TGDC): Clinical presentation, diagnosis, and management. Am J Otolaryngol [Internet]. Elsevier; 1996 Sep 9 [cited 2014; Oct 15]; 17: 353-7.

10. Deshpande A, Bobhate SK. Squamous cell carcinoma in thyroglossal duct cyst. J Laryngol Otol [Internet]. Cambridge University Press; 2007 Jun 29 [cited 2014 Sep 21]; 109:1001-4.

11. White IL, Talbert WM. Squamous cell carcinoma arising in thyroglossal duct remnant cyst epithelium. Otolaryngol Head Neck Surg [Internet]. 1982 Jan 2 [cited 2014 Sep 21]; 90: 25-31.

12. Yanagisawa K, Eisen RN, Sasaki CT. Squamous cell carcinoma arising in a thyroglossal duct cyst. Arch Otolaryngol - Head Neck Surg [Internet]. American Medical Association; 1992 May 1 [cited 2014 Sep 21]; 118: $538-41$.

13. Livolsi V. The american journal of surgical pathology [Internet]. The American Journal of Surgical Pathology 1978. 